\title{
STRUKTUR MODAL DAN MODAL KERJA PT XYZ SERTA PENGARUHNYA TERHADAP KINERJA PERUSAHAAN
}

\author{
Untung Setiono*)1, Hermanto Siregar ${ }^{* *}$, dan Lukytawati Anggraeni**) \\ ${ }^{*}$ Sekolah Bisnis, Institut Pertanian Bogor \\ Jl. Raya Pajajaran, Bogor 16151 \\ **) Departemen Ilmu Manajemen, Fakultas Ekonomi dan Manajemen, Institut Pertanian Bogor \\ Jl. Kamper Wing 4 Level 5 Kampus IPB, Bogor, Jawa Barat 16680
}

\begin{abstract}
In 2012, the electronic payment system transactions reached IDR 104.830 trillion or increase 46,52\% from the previous year. PT. XYZ is the pioneer in the electronic payment system Indonesia and still one of the leading companies in electronic payment system interbank, through ATM (Automatic Teller Machine) and EDC (Electronic Data Capture) in Indonesia. In 2012 the company spent USD 3,4 million on software tandem from a foreign vendor. Therefore it is important to study (1) policy on the modal structure of the company, (2) the working capital policy of the company, (3) the monetary performance relationship of the company based on the 2 policies. The method used to analyze the data is multiple linear regression analysis; this method is used to calculate the relationship between the structure variable of the capital and working capital. The result is; 1) the structure policy on the capital of the company is in accordance with the Pecking Order theory where the company uses their own capital before applying the long term debt to the others, 2) the inefficient policy on the company's working capital is because most of the active asset is in monthly deposit bonds and even extended the active debt, 3) the relationship between short term debt and liquidity ratio is negative while the total debt (short and long term) has a positive correlation with the solvability/leverage ratio of the company. The research recommends the management to decrease the active asset and uses it for long term investment not only for timed deposit.
\end{abstract}

Keywords: ATM, EDC, capital structure, financial performance

\begin{abstract}
ABSTRAK
Voulme transaksi dalam menggunakan sistem pembayaran elektronis pada tahun 2012 mencapai Rp104.830 triliun atau meningkat sekitar 46,52\% dari tahun sebelumnya. PT XYZ adalah salah satu perusahaan pionir dalam sistem bidang pembayaran elektronis di Indonesia dan tetap menjadi pemain utama dalam sistem pembayaran elektronis antar bank, ATM (Automatic Teller Machine) dan EDC (Electronic Data Capture). Di tahun 2012 perusahaan membeli software tandem dari vendor luar negeri dimana menghabiskan dana USD 3,4 juta, dengan pembelian ini maka dari itu penting untuk di teliti: 1) kebijakan struktur modal perusahaan, 2) kebijakan modal kerja perusahaan dan 3) hubungan kinerja keuangan perusahaan berdasarkan dua kebijakan tersebut. Metode yang digunakan adalah analisis regresi linier berganda, mengukur hubungan variabel struktur modal dan modal kerja perusahaan. Pada penelitian telah menemukan: 1) kebijakan struktur modal perusahaan sejalan dengan teori Pecking Order, dimana perusahaan lebih menggunakan dana modal sendiri sebelum menggunakan hutang jangka panjang pada pihak lain, 2) kebijakan modal kerja perusahaan kurang efisien, dikarenakan sebagian besar asset lancar adalah dalam bentuk deposito berjangka bulanan dan bahkan melebihi hutang lancer itu sendiri, dan 3) hubungan antara hutang jangka pendek dan rasio likuiditas adalah negative, sedangkan total hutang (jangka pendek dan jangka panjang) berkorelasi positif dengan rasio solvabilitas/leverage perusahaan. Penelitian ini menyimpulkan manajemen untuk lebih mengurangi asset lancer mereka dan lebih menggunakan asset tersebut untuk investasi jangka panjang, bukan hanya untuk deposito berjangka.
\end{abstract}

Kata kunci: ATM, EDC, regresi, struktur modal, kinerja keuangan

\footnotetext{
${ }^{1}$ Alamat Korespondensi:

Email: untung_stn@yahoo.co.id
} 


\section{PENDAHULUAN}

Perekonomian Indonesia pada tahun 2013 tumbuh sebesar 5,78\% dibandingkan tahun 2012, dimana semua sektor ekonomi mengalami pertumbuhan. Pertumbuhan tertinggi terjadi pada sektor pengangkutan dan komunikasi yang mencapai 10,19\% diikuti oleh sektor keuangan, real estate, dan jasa perusahaan 7,56\%, sektor konstruksi 6,57\%, sektor perdagangan, hotel dan restoran 5,93\%, sektor listrik, gas dan air bersih 5,58\%, sektor industri pengolahan 5,56\%, sektor jasa-jasa $5,46 \%$, sektor pertanian 3,54\%, dan sektor pertambangan dan penggalian $1,34 \%$. Pertumbuhan PDB tanpa migas pada tahun 2013 mencapai 6,25\% yang berarti lebih tinggi dari pertumbuhan PDB (BPS, 2014).

Infrastruktur yang dibangun industri perbankan dan pembayaran elektronik juga tak lepas dari dukungan payung hukum Bank Indonesia (BI) selaku regulator sistempembayarannasionalsehinggaprosespembayaran elektronik pun berjalan kontinyu. Bank Indonesia pun secara konsisten terus berupaya meningkatkan kinerja sistem pembayaran sebagai urat nadi perekonomian Indonesia, upaya tersebut telah menunjukan hasil yang baik, yaitu dengan semakin meningkatnya peran sistem pembayaran dalam mendukung aktivitas ekonomi masyarakat. Sesuai data transaksi keuangan melalui sistem pembayaran, selama tahun 2012 nilai transaksi mencapai Rp104.83 ribu triliun atau meningkat 46,52\% dari nilai transaksi tahun 2011 yang tercatat sebesar Rp71,55 ribu triliun. Sementara itu volume transaksi mencapai $3,27 \%$ miliar transaksi atau meningkat sebesar $24,42 \%$ dari volume transaksi tahun 2011 yang mencapai 2,63\% miliar transaksi (BI, 2012).

Pada akhir periode laporan oleh BI tahun 2012, tercatat total kartu ATM dan ATM/Debet yang beredar mencapai 77,75 juta kartu. Jumlah tersebut meningkat sebesar $21,15 \%$ dibandingkan dengan akhir periode laporan sebelumnya yang mencapai 63,39 juta kartu. Dari jumlah tersebut sebanyak 73,22 juta kartu $(94,17 \%)$ merupakan kartu ATM/Debet, yang selain berfungsi untuk melakukan transaksi di terminal ATM, juga dapat berfungsi sebagai kartu debet untuk digunakan dalam transaksi belanja di pedagang. Dengan peningkatan jumlah kartu ATM dan ATM/Debet beredar tersebut, mendorong peningkatan aktivitas transaksi menggunakan kartu ATM dan ATM/Debet. Pada periode tersebut, nilai transaksi menggunakan kartu ATM dan ATM Debet mencapai Rp3,07 ribu triliun atau meningkat sebesar $23,74 \%$ dibandingkan dengan periode sebelumnya yang mencapai Rp2,48 ribu triliun.

PT. XYZ sebagai salah satu dari tiga perusahaan yang dizinkan oleh Bank Indonesia dalam menjalankan bisnis transfer dana atau jasa pembayaran elektronik, harus memperluas jaringan ataupun menambah fitur dan aplikasi transaksi elektronik dengan biaya yang tidak sedikit dalam berinvestasi di bidang teknologi dan informasi jika ingin bertahan menjadi perusahaan pembayaran elektronis terdepan di Indonesia. Hutang leasing atau hutang jangka panjang yang dilakukan PT. XYZ dalam bentuk dollar adalah hutang jangka panjang paling signifikan yang pernah dilakukan oleh perusahaan. Selama ini perusahaan juga tidak mempunyai hutang jangka panjang dari bank, hanya mempunyai hutang jangka pendek (dibawah satu tahun) seperti yang tersebut diatas. Belum pernah ada perhitungan mengenai dampak dari besaran hutang terhadap struktur modal perusahaan, apakah normal bagi perusahaan atau justru sebaliknya.Dimulai pada tahun 2012 dimana perusahaan memutuskan untuk membeli mesin tandem dari vendor HPFI yang berpusat di Amerika Serikat dengan cara Sale and Lease Back. Jumlah total pembelian aset tersebut adalah sebesar \$5.471.664 dengan bunga leasing sebesar \$338.336 jika dirupiahkan dengan kurs pembukuan saat itu Rp9.565/USD total pembelian tersebut mencapai Rp52.336.466.160 dengan bunga leasing Rp3.236.183.840 (Tabel 1)

Gambar 3 membandingkan piutang perusahaan dengan dana kas yang ada di perusahaan, terlihat terjadi stagnantasi dari jumlah piutang perusahaan selama lima tahun terakhir.Hal ini mengindikasikan tidak terjadinya perputaran arus kas seperti yang diharapkan, dana lebih banyak mengendap di kas/bank perusahaan selama lima tahun terakhir. Selama tiga tahun terakhir perusahaan juga lebih banyak investasi pada deposito berjangka tiga bulan atau deposito on call di berbagai bank, agar dana yang ada berputar dan menghasilkan bunga. Sebaliknya, pada Gambar 4 menunjukkan perbandingkan jumlah kas ditangan dengan deposito berjangka bulanan, terlihat bagaimana perbandingan kas ditangan dengan saldo deposito selama tiga tahun terakhir yang hampir $70 \%$ dari total aktiva lancar perusahaan. 
Tabel 1. Saldo hutang leasing PT. XYZ tahun 2012-2013 (dalam jutaan)

\begin{tabular}{|c|c|c|c|c|c|c|c|c|}
\hline \multirow{2}{*}{ Bulan } & \multirow{2}{*}{ Keterangan } & \multirow{2}{*}{$\begin{array}{l}\text { Amount } \\
\text { USD }\end{array}$} & \multirow{2}{*}{ Kurs } & \multirow{2}{*}{ Total IDR } & \multicolumn{3}{|c|}{ Mutasi pembayaran } & \multirow{2}{*}{ Saldo akhir } \\
\hline & & & & & Amount & Kurs beli & Total IDR & \\
\hline \multirow[t]{2}{*}{01 Mei 2012} & $\begin{array}{l}\text { Sale \& lease back- } \\
\text { HPFI }\end{array}$ & 5,4 & 9.565 & 52.336 & & & & 52.336 \\
\hline & Bunga leasing & 0,33 & 9.565 & 3.236 & & & & 55.572 \\
\hline 14 Mei 2012 & $\begin{array}{l}\text { Pembayaran tahap } 1 \\
\text { leasing }\end{array}$ & & & & 1,2 & 9.565 & 11.478 & 44.094 \\
\hline $\begin{array}{l}14 \text { September } \\
2012\end{array}$ & $\begin{array}{l}\text { Pembayaran tahap } 2 \\
\text { leasing }\end{array}$ & & & & 1,2 & 9.588 & 11.505 & 32.589 \\
\hline 02 April 2013 & $\begin{array}{l}\text { Pembayaran tahap } 3 \\
\text { leasing }\end{array}$ & & & & 1,7 & 9.722 & 16.576 & 16.013 \\
\hline \multirow[t]{2}{*}{$\begin{array}{l}21 \text { Oktober } \\
2013\end{array}$} & $\begin{array}{l}\text { Pembayaran tahap } 4 \\
\text { leasing }\end{array}$ & & & & 1,7 & 11.234 & 19.153 & $(3.140)$ \\
\hline & & & & & 5,8 & Rugi se & sih kurs & $(3.140)$ \\
\hline
\end{tabular}

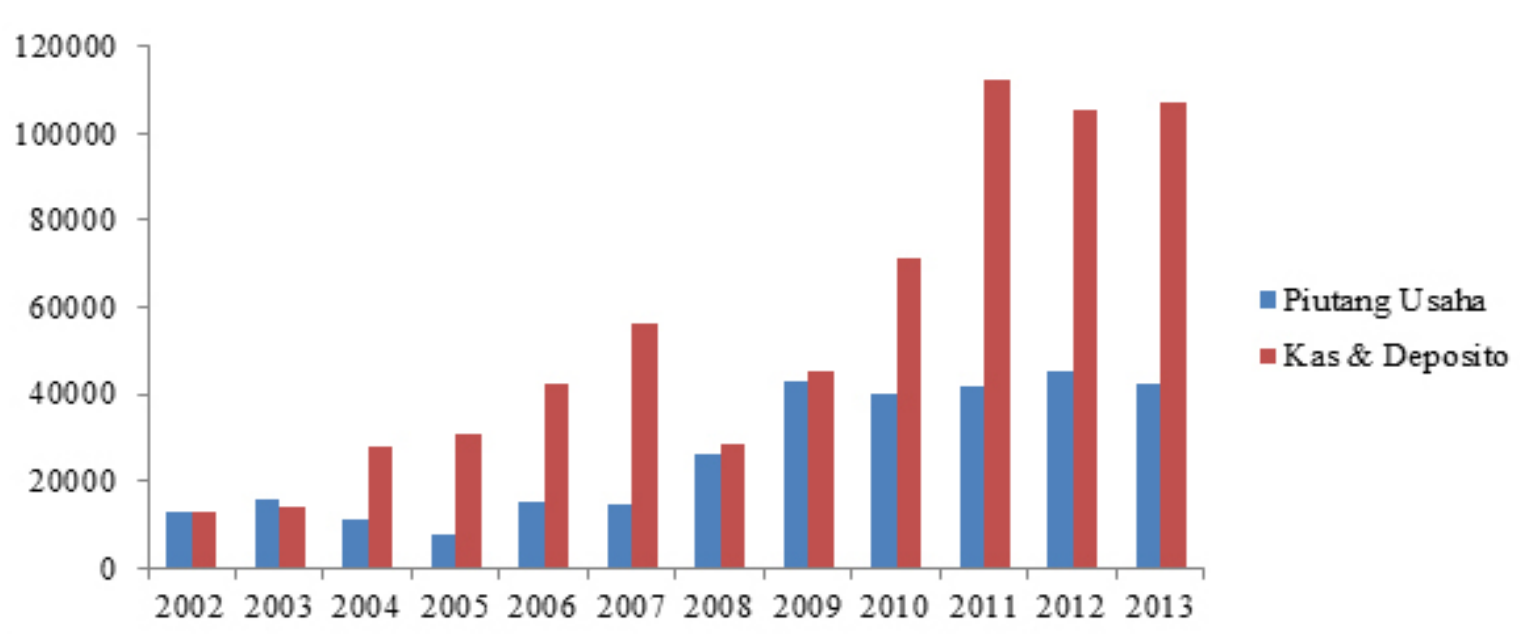

Gambar 3. Perbandingan saldo piutang dan saldo kas PT XYZ tahun 2002-2013 (dalam jutaan)

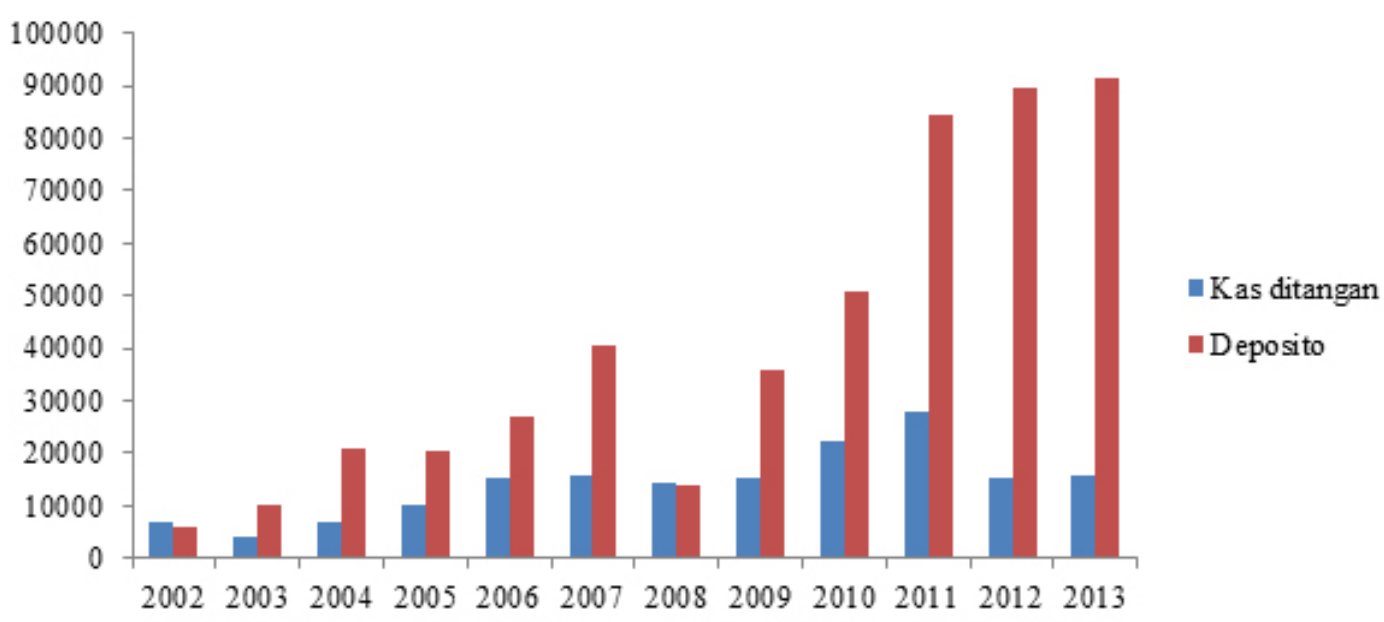

Gambar 4. Perbandingan kas ditangan dengan saldo deposito berjangka 3 bulan (dalam jutaan) 
Berdasarkan pokok permasalahanyang telah disebutkan, tujuan dari penelitian adalah untuk menganalisis struktur modal PT XYZ selama periode 2002-2013, menganalisis modal kerja PT XYZ selama periode 2002-2013, dan menganalisis pengaruh struktur modal dan modal kerja pada kinerja perusahaan.

\section{METODE PENELITIAN}

Penelitian ini merupakan studi kasus pada perusahaan yang dipilih dengan menggunakan pendekatan kuantitatif, pendekatan ini lebih berdasarkan pada data untuk mendapatkan penaksiran kuantitatif yang kuat. Penelitian ini dilakukan di PT XYZ yang berlokasi di Jakarta Pusat, waktu penelitian mulai dari bulan november 2014-Agustus 2015. PT XYZ merupakan perusahaan yang bergerak di bidang IT dengan jasa layanan utamanya sebagai jasa penyedia pembayaran elektronik di Indonesia. Data yang digunakan dalam penelitian ini adalah data kuantitatif, sumber data merupakan hasil laporan keuangan tahunan PT. XYZ yang sudah diaudit oleh auditor independent. Data laporan keuangan meliputi data laporan laba-rugi, neraca, arus kas, perubahan modal mulai tahun 2002 sampai tahun 2013.

\section{Analisis Struktur Modal}

Teori struktur modal yang dikembangkan oleh beberapa ahli, terutama digunakan untuk mengetahui apakah perusahaan bisa meningkatkan kemakmuran pemegang saham melalui perubahan dari struktur modal. Berikut variabel yang digunakan dalam berbagai formulasi struktur modal (Sutrisno, 2012) sebagai berikut: Nilai perusahaan $\left(\mathrm{V}_{\mathrm{L}}\right)=$ Nilai Pasar hutang $(\mathrm{B})+$ Nilai pasar modal sendiri (S)

Sebuah studi literatur besar pada bidang akuntansi dan keuangan telah dilakukan dalam mengidentifikasi apa yang mendorong salah satu kebijakan-kebijakan yang dilakukan oleh perusahaan, yaitu keputusan dalam struktur modal (capital structure decision). Studi dilakukan pertama kali oleh Modigliani dan Miller (1958) dalam menganalisis masalah tersebut, menyimpulkan bahwa struktur modal dan nilai dari suatu perusahaan tidak berhubungan. Dalam kurun waktu lima tahun kemudian (Modigliani dan Miller, 1958), menemukan bahwa nilai dari suatu perusahaan akan meningkat bersamaan dengan kenaikan hutang perusahaan setelah memasukan efek pasar sempurna dan pajak perusahaan. Dalam model tersebut menyimpulkan bahwa bunga yang dibayarkan dari hutang jangka panjang dapat menjadi pengurang pajak perusahaan.

\section{Teori Trade Off dan Pecking Order}

Selain teori Modigliani dan Miller, terdapat model teori yang dapat menjelaskan juga mengenai struktur modal perusahaaan. Trade off menjelaskan gabungan antara hutang dan ekuitas yang dapat mencapai keseimbangan antara keuntungan pajak atas hutang dan biaya-biaya jika menggunakan hutang yang akan dipilih oleh manajemen perusahaan (Wet, 2006). Model teori yang kedua dikenal dengan nama pecking order theory. Teori ini menjelaskan pihak manajemen perusahaan memiliki informasi asimetris dimanamanajemen merupakan pihak yang paling mengetahui mengenai peluang investasi perusahaan. Situasi ini menyebabkan manajemen menaikan pendanaan berdasarkan urutan. Adapun urutan tersebut dimulai dari akumulasi laba yang ditahan, kemudian pinjaman, saham preferen dan yang terakhir adalah menerbitkan saham baru (Wet, 2006). Model ini lebih mementingkan motivasi dari manajer perusahaan dibandingkan dengan dasar valuasi pasar modal. Gill et al. (2011), Shubita dan Alsawalhah (2012) dalam penelitiannya mengemukakan dalam pengukuran struktur modal perusahaan dapat ditempuh dengan tiga jenis rasio utang terhadap total aset sebagai berikut:

SDA $($ Short term debt $)=$ Hutang jangka pendek/Total aset

LDA $($ Long term debt $)=$ Hutang jangka panjang $/($ Total aset

DA $($ Total debt $)=$ Total hutang/Total aset

\section{Analisis Modal Kerja}

Setiap perusahaan yang melakukan kegiatannya selalu membutuhkandana. Kebutuhan dana tersebut digunakan untuk membiayai kebutuhan investasi maupun untuk memenuhi kebutuhan operasional sehari-hari. Dana yang dibutuhkan oleh perusahaan untuk memenuhi kebutuhan operasional sehari-hari, seperti pembelian bahan baku, pembayaran upah buruh, membayar hutang dan pembayaran lainnya disebut modal kerja (Sutrisno, 2012). 


\section{Manajemen Modal Kerja}

Abbadi dan Abbadi (2013) mengemukakan bahwa selain total aset, kebutuhan akan modal kerja juga dipengaruhi oleh operating cash flow (OCF) dan cash convertion cycle (CCC). Operating Cash Flow (OCF) adalah kas perusahaan yang diperoleh secara rutin, arus kas operasi yang positif memungkinkan perusahaan untuk membiaya kebutuhan modal kerja, memungkinkan strategi modal kerja operasi yang lebih konservatif (aktiva lancar $>$ kewajiban lancar)sehingga memfasilitasi pertumbuhan penjualan dimasa yang akan datang (Ranjith, 2008), OCF di hitung dengan cara:

$$
\mathrm{OCF}=(\mathrm{EBIT}+\text { Depreciation }- \text { Taxes }) / \text { Total Assets }
$$

Cash Conversion Cycle (CCC) siklus ini didefinisikan sebagaijumlahhariyangdibutuhkanuntukmengkonversi pembelian dari bahan mentah sampai menjadi produk jadi dan menjualnya untuk mendapatkan dana kas. Semakin lama siklus semakin besar investasi dalam aktiva lancar dan membuat semakin besar kebutuhan untuk pembiayaan aktiva lancar. Siklus ini dihitung dengan cara:

$\mathrm{CCC}=$ Averegae collection period + inventory turnovers in days - Average payment period

Dalam penelitiannya Chiou et al. (2006), Ranjith (2008) melakukan formula pengukuran modal kerja sebagai berikut:

Working Capital Requirement $(\mathrm{WCR})=[($ account receivables + inventories)- (account payable + other payable)]

Net Liquid Balance $(\mathrm{NLB})=[($ cash and cash equivalents + short-term investment)-(short term debt + commercial paper payable + long-term debt a year term)]

\section{Analisis Kinerja Laporan Keuangan}

Rasio keuangan merupakan cara membandingkan dan menyelidiki hubungan antara berbagai potonganpotongan dari informasi keuangan (Ross et al. 2010). Rasio profitabilitas, pengukuran ini bertujuan untuk mengukur seberapa efisien PT. XYZ menggunakan asetasetnya dan seberapa efisien perusahaan bisa mengatur operasinya, Return on equity (ROE) adalah pengukuran bagaimana kondisi pemegang saham selama tahun berjalan. Karena memberikan keuntungan untuk pemegang saham adalah tujuan utama perusahaan, ROE adalah inti dari pengukuran kinerja perusahaan.

$$
\mathrm{ROE}=\text { Net Income/Total equity }
$$

Rasio likuiditas (LIQ), menyediakan informasi mengenai tingkat likuiditas dari sebuah perusahaan. Tujuan dari perhitungan ini rasio ini untuk menilai kemampuan PT. XYZ untuk membayar hutang perusahaan jangka pendek tanpa mengalami financial distress. Current ratio merupakan rasio antara current assets terhadap current liabilities. Secara persamaan dapat ditulis sebagai berikut :

\section{Current ratio $=$ Current Assets $/$ Current Liabilities}

Rasio solvabilitas/leverage (LEV), rasio ini melihat kemampuan PT. XYZ dalam membayar kewajibankewajiban jangka panjangnya. Jika PT XYZ gagal membayar hutang tersebut bisa dinyatakan bangkrut.

Debt to Equity Ratio= Total hutang/Modal x 100\%

\section{Analisis Regresi Linier Berganda}

Menurut Hair et al. (2006) analisis regresi berganda adalah metode yang paling tepat dilakukan dalam analisis dimana masalah penelitian bermaksud mengetahui sebuah variabel bebas dianggap berhubungan dengan dua atau lebih variabel tidak bebas. Dalam mengukur struktur modal Gill et al. (2011), Shubitta dan Alsawalhah (2012) menggunakan variabel perbandingan hutang jangka pendek per total aset (SDA),hutang jangka panjang per total aset (LDA) dan total hutang per total aset (DA). Sementara Chiou et al. (2006), dan Ranjith (2008) mengukur modal kerja dengan net liquid balance (NLB) dan working capital requirements (WCR). Sementara itu, Ross et al. (2010) mengemukakan dalam mengukur kinerja perusahaan adalah dengan menggunakan rasio-rasio keuangan, antara lain rasio profitabilitas (ROE), likuiditas (LIQ) dan solvabilitas/leverage (LEV).

$\mathrm{ROE}=\alpha_{0}+\alpha_{1} \quad \mathrm{NLB}+\alpha_{2} \quad \mathrm{WCR}+\alpha_{3} \quad \mathrm{SDA}+\alpha_{4} \quad \mathrm{LDA}+\alpha_{5}$ $\mathrm{DA}+\mu_{\mathrm{i}, \mathrm{t}}$

$\mathrm{LIQ}=\beta_{0}+\beta_{1} \mathrm{NLB}+\beta_{2} \mathrm{WCR}+\beta_{3} \mathrm{SDA}+\beta_{4} \mathrm{LDA}+\beta_{5}$ $\mathrm{DA}+\mu_{\mathrm{i}, \mathrm{t}}$

$\mathrm{LEV}=\theta_{0}+\theta_{1} \mathrm{NLB}+\theta_{2} \mathrm{WCR}+\theta_{3} \mathrm{SDA}+\theta_{4} \mathrm{LDA}+\theta_{5}$ $\mathrm{DA}+\mu_{\mathrm{i}, \mathrm{t}}$ 


\section{HASIL}

\section{Analisis Struktur Kerja}

\section{Analisis Modigliani Miller II}

Pendekatan yang digunakan peneliti dalam menghitung struktur modal PT. XYZ adalah dengan pendekatan Modigliani Miller II (1958) dengan asumsi pajak 25\%. Tarif pajak 25\%adalah tarif pajak korporasi di Indonesia sesuai dengan peraturan pemerintah No.46 tahun 2013 tentang pajak penghasilan atas penghasilan dari usaha yang diterima dan diperoleh wajib pajak yang memiliki peredaran bruto tertentu. Menurut teori MM II, bahwa pendekatan nilai perusahaan asumsi dengan pajak akan semakin besar diiringi dengan semakin besarnya hutang (Gambar 5). Data yang diolah peneliti menunjukan rasio paling besar hutang perusahaan terhadap pasiva adalah ketika tahun 2012, ketika perusahaan memutuskan untuk melakukan transaksi hutang leasing (sale and leasee back) sekitar 32\% dari nilai perusahaan itu sendiri. Menurut teori MM II maka biaya modal perusahaan harusnya menjadi paling rendah ditahun 2012, atau nilai perusahaan menjadi paling tinggi jika diasumsikan EBIT perusahaan stagnan.

Hutang perusahaan juga mengalami peningkatan, terutama hutang jangka pendek, hutang jangka panjang perusahaan hanya meningkat signifikan pada tahun 2013, ketika perusahaan memtuskan untuk membeli server dari luar negeri dengan cara leasing. Total hutang jangka pendek dan jangka panjang berkorelasi positif dengan bertambahnya jumlah aktiva tetap berwujud perusahaan (Mouamer, 2011). Hal tersebut dikarenakan PT XYZ membeli server dengan cara hutang leasing atau hutang jangka panjang yang masanya lebih dari satu tahun, dengan model hutang leasing tersebut PT XYZ mengharapkan kemudahan dalam pembelian server karena pembayaran server tersebut memakai aktiva lancar perusahaan, keputusan manajemen sepertinya tidak ingin membuat pemegang saham ragu-ragu atas aktiva perusahaan, namun manajemen juga tidak ingin meminjam dana dari bank atas transaksi tersebut.

\section{Teori Pecking Order dan Trade Off}

PT XYZ lebih mementingkan investor agar mendapat return yang tetap, dimana mengeluarkan surat utang ataupun saham adalah cara terakhir yang ditempuh ketika perusahaan benar-benar membutuhkan tambahan modal. Ketakutan terbesar para investor PT XYZ adalah terjadinya misspricing pada surat utang ataupun saham tersebut. Menurut Eldomiaty (2007) pada perusahaan yang menganut teori pecking order, struktur modal perusahaan akan lebih dipengaruhi oleh pertumbuhan perusahaan, dan profitabilitas, hal ini juga sejalan dengan yang terjadi pada PT XYZ, dimana pada tahun pembukuan 2002-2013, perusahaan tumbuh seiring dengan meningkatnya profitabilitas, (Gambar 6), dimana laba ditahan perusahaan meningkat setiap tahunnya dan mencapai titik tertinggi pada tahun 2008 dan 2009 dimana pertambahan modal menjadi sekitar $83 \%$ dari total nilai perusahaan, pada tahun 2009 EBIT perusahaan meningkat sekitar $62 \%$ dari tahun sebelumnya.

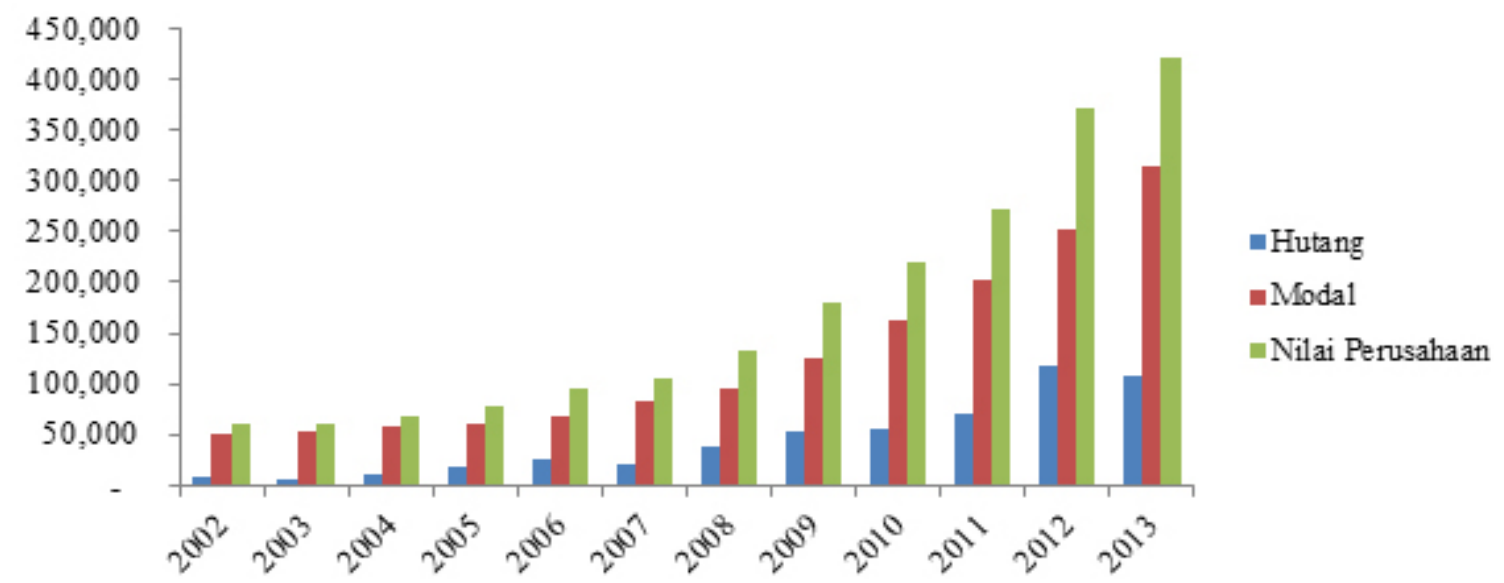

Gambar 5. Nilai perusahaan PT. XYZ tahun buku 2002-2013 (dalam jutaan) 


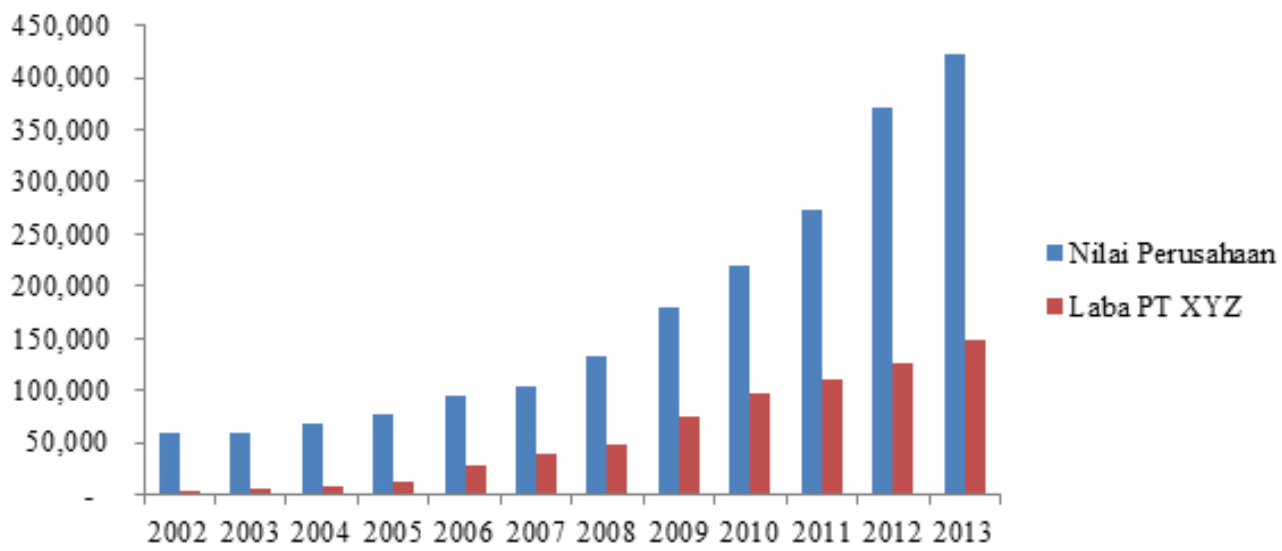

Gambar 6. Perbandingan nilai perusahaan dengan laba usaha PT XYZ tahun buku 2002-2013 (dalam jutaan)

Disisi lain teori pecking order juga berasumsi bahwa manager bertindak untuk kepentingan pada pemegang saham dengan tujuan memaksimalkan nilai dari saham yang ada (Myers dan majluf, 2001), peningkatan modal perusahaan yang tumbuh pesat hingga akhir 2013, juga memaksimalkannilai saham perusahaan sesuai dengan keinginan dari pemegang saham. Harga saham PT. XYZ ketika awal didirikan adalah Rp1.000.000/lembar saham. Namun, jika dihitung kembali pada tahun 2013, ditambah dengan laba ditahan pada modal perusahaan, nilai saham perusahaan mencapai Rp6.073.467/lembar saham, dengan proporsi dividen yang telah ditentukan dan dibagikan setiap tahun pada masing-masing pemegang saham, semakin tinggi nilai saham semakin tinggi nominal dividen yang dibagikan.

\section{Analisis Modal Kerja}

\section{Analisis Modal Kerja Bersih (Net working Capital)}

Analisis ini menggambarkan keputusan manajemen dalam mengelola modal kerja untuk menjalankan kegiatan produksinya. Analisis ini menggunakan perbandingan antara aktiva lancar dan hutang lancar. Perbandingan aktiva lancar dan hutang lancar perusahaan dari tahun 2002 sampai dengan tahun 2013 perusahaan dalam melakukan kegiatan usahanya bernilai positif. Hal ini menggambarkan bahwa pendanaan kegiatan produksi perusahaan dibiayai oleh aktiva lancar atau dapat dikatakan dengan hasil yang didapatkan perusahaan selama 12 tahun dari mulai tahun 2002 sampai 2013 menggunakan pendekatan konservatif. Pendekatan ini memiliki risiko likuiditas lebih rendah dan hasil juga lebih rendah. PT. XYZ menggunakan modal dalam mendanai hampir seluruh aktiva tetap, aktiva lancar dan aktiva lancar temporer.
Dari tahun 2002 sampai tahun 2013 perusahaan menggunakan pendekatan konservatif dalam mengelola modal kerjanya, setiap tahun aktiva lancar perusahaan hampir selalu lebih besar daripada kewajiban lancar perusahaan, perbedaan terkecil terjadi pada tahun 2012, dimana terdapat transaksi hutang leasing (sale and leasee back), dimana transaksi tersebut dicatat sebagai hutang lancar oleh auditor, yang efeknya modal kerja perusahaan pada tahun tersebut paling besar ketimbang tahun-tahun sebelumnya, yaitu sekitar Rp55 miliyar. Rasio antara aktiva lancar dan kewajiban lancar pun paling tinggi di tahun 2012, dimana rasio kewajiban lancar mencapai $66 \%$ dibanding dengan aktiva lancar, lalu kemudian menurun kembali ke kisaran 57\% di tahun 2013 (Gambar 7). Pada tahun yang sama terjadi perbedaan signifikan pada aset yang dikelola perusahaan, dimana pertama kali sejak perusahaan didirikan aset tetap $>$ aset lancar. Secara menyeluruh perusahaan ingin menggambarkan posisi keuangan yang sehat, dan menjalankan kebijakan modal kerja yang konservatif (aktiva lancar > kewajiban lancar) agar pemegang saham tidak khawatir.

Manajemen modal kerja harus tetap dijalankan secara efisien dan tepat, ketika kebutuhan modal kerja yang dikelola kurang baik, dalam artian dialokasikan lebih dari yang dibutuhkan, seperti halnya terjadi pada PT. $\mathrm{XYZ}$ dapat menciptakan manajemen yang tidak efisien dan mengurangi manfaat dari investasi jangka pendek (Nazir dan Afza, 2009). Pentingnya pengelolaan kebutuhan modal kerja karena untuk memastikan peningkatan nilai dan profitabilitas dari PT. XYZ itu sendiri, dan aspek ini harus menjadi bagian dari pemikiran strategis dan operasional perusahaan secara efektif dan efisien (Azhar dan Noriza, 2010). Proporsi tidak berimbang antara aktiva lancar dan hutang lancar juga berakibat kurangnya manajemen modal kerja 
PT XYZ dalam melakukan investasi. Proporsi yang menggambarkan perusahaan sudah merencanakan pembiayaan atau operasional dalam jangka panjang adalah ketika jumlah aktiva lancar sama dengan net working capital (NWC) sama pada kolom aktiva, sedangkan pada kolom pasiva jumlah hutang jangka panjang dan modal perusahaan berada di atas hutang lancar (Belt, 1979).

\section{Hasil Analisis Regresi Linier Berganda}

Pada Tabel 2, dapat dilihat persamaan ROE,mempunyai hasil signifikan pada variabel SDA dengan probabilitas 0,0235 atau bisa dinyatakan hutang jangka pendek pada perusahaan berpengaruh signifikan pada ROE,hal ini sesuai dengan penelitian dari Gill et al. (2011), Shubita dan Alsawalhah (2012) yang menyatakan terjadi hubungan signifikanantara SDA, LDA dengan rasio profitabilitas (ROE). Pada persamaan LIQ diperoleh hasil signifikan negatif pada variabel SDA dengan probabilitas 0,0250 maka dapat disimpulkan bahwa SDA secara parsial memiliki pengaruh signifikan yang negatif terhadap Rasio Likuiditas pada periode t. Pada persamaan LIQ, diperoleh hanya variabel SDA yang memiliki pengaruh signifikan,hal ini sesuai dengan penelitian Kajananthan dan Achchuthan (2013) dimana penelitian menyimpulkan bahwa terjadi hubungan signifikan antara rasio likuiditas dengan rasio hutang terhadap modal. Namun, persamaan LIQ tidak menemukan adanya hubungan signifikan antara rasio likuiditas dengan variabel modal kerja (NLB dan WCR), berbeda dengan penelitian Shah (2012) yang mengemukakan bahwa terjadi hubungan yang signifikan antara rasio likuiditas dengan variabel modal kerja.

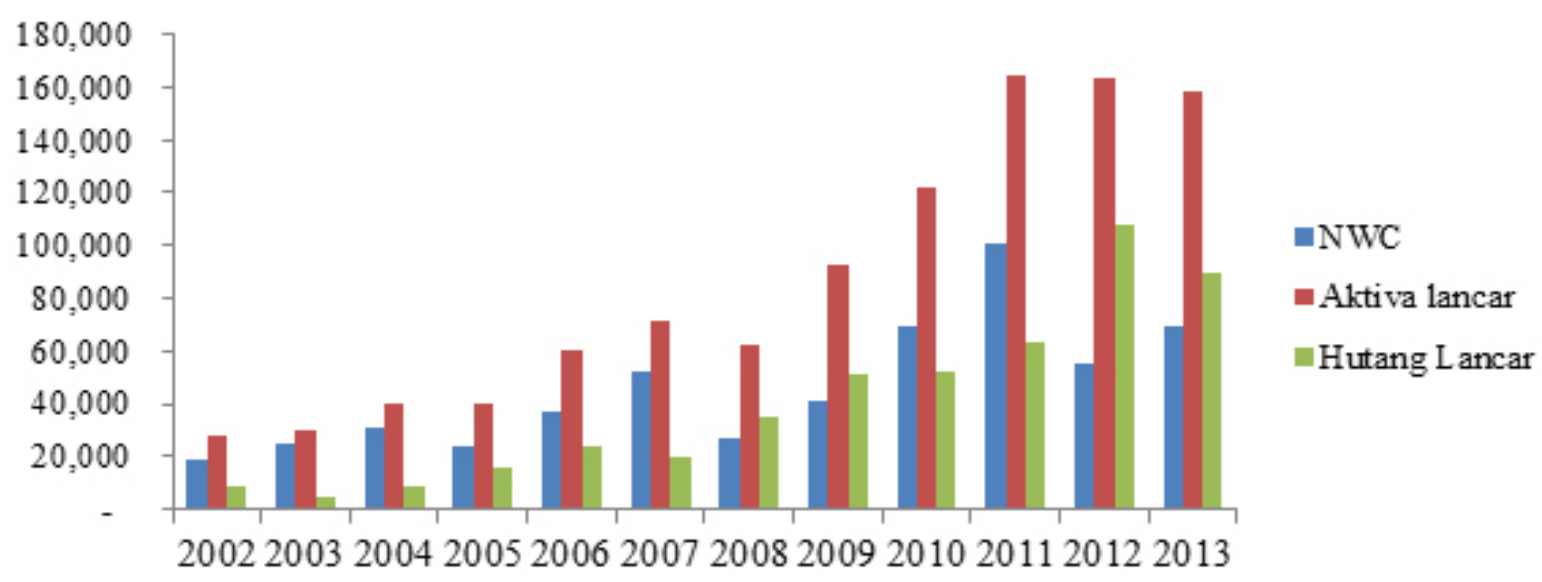

Gambar 7. Pertumbuhan net working capital, aktiva lancar, dan hutang lancar PT XYZ tahun buku 2002 - 2013 (dalam jutaan rupiah).

Tabel 2.Hasil analisis regresi linier berganda persamaan ROE, LIQdan LEV dengan Eviews 7.

\begin{tabular}{lcccccc}
\hline & \multicolumn{2}{c}{ ROE } & \multicolumn{2}{c}{ LIQ } & \multicolumn{2}{c}{ LEV } \\
\hline Coef & Prob & Coef & Prob & Coef & Prob \\
\hline NLB & $-0,149654$ & 0,5612 & $5.343,599$ & 0,0046 & $-0,065125$ & 0,0055 \\
WCR & $3,93 \mathrm{E}-12$ & 0,2124 & $9,71 \mathrm{E}-12$ & 0,5166 & $-3,22 \mathrm{E}-13$ & 0,1207 \\
SDA & $-3,47 \mathrm{E}-12$ & 0,6864 & $7,38 \mathrm{E}-11$ & 0,1212 & $4,18 \mathrm{E}-13$ & 0,4497 \\
LDA & $3.431,439$ & $0,0235^{*}$ & $-1.687,803$ & $0,0250^{*}$ & $1.542,873$ & $0,0000^{*}$ \\
DA & 0,8674 & 0,8363 & $2.217,316$ & 0,3120 & $1.896,183$ & $0,0003^{*}$ \\
\hline R-Squared & $-0,4757$ & 0,3734 & 0,773790 & 0,7649 & 0,023026 & 0,4889 \\
\hline Adj R-Squared & \multicolumn{2}{c}{0,7891} & 0,9027 & \multicolumn{2}{c}{0,9974} \\
\hline Prob (F-Statistic) & \multicolumn{3}{c}{0,6134} & 0,8217 & \multicolumn{2}{c}{0,9953} \\
\hline
\end{tabular}


Pada Persamaan LEV diperoleh dua variable yang signifikan, yaitu variabel SDA dan LDA, dimana probabilitas SDA mencapai 0,0000 terhadap LEV, dan LDA mempunyai pengaruh signifikan 0,0003 terhadap LEV, persamaan LEV merupakan satu-satunya persamaan dimana terjadi lebih dari satu variabel independen yang berpengaruh signifikan terhadap dependennya, hasil ini sesuai dengan penelitian Nurdin (2013), yang menyatakan LEV atau disebut juga debt equity ratios (DER) berpengaruh signifikan terhadap pengelolaan hutang perusahaan atau pengelolaan capital structure.

Perbandingan antara rasio profitabilitas (ROE) pada Gambar 8, dimana terlihat bahwa profitabilitas perusahaan berjalan hampir secara beriringan dengan rasio hutang jangka pendek (SDA) pada PT XYZ, perbedaan alur SDA hanya terjadi pada saat tahun 2002, 2010, 2011 dan 2012, dimana SDA atau hutang jangka pendek terlihat lebih besar dari pada profitabilitas perusahaan atau lebih besar dibanding proporsi tahuntahun sebelumnya, hal tersebut dapat dijelaskan bahwa pada tahun 2002, perusahaan baru berdiri selama satu tahun sehingga belum mendapatkan laba yang tinggi, sedangkan pada tahun 2010, perusahaan membeli aset berupa tanah untuk investasi pembangunan gedung baru, hal ini Memengaruhi SDA karena jumlah aset yang dimiliki jadi lebih besar, begitupun dengan tahun 2012,
SDA jadi terlihat lebih kecil dikarenakan pembelian software tandem dengan cara hutang leasing, dimana pengakuan asetnya dilakukan $100 \%$ pada tahun 2012 meskipun belum lunas.

Khusus untuk SDA,atau rasio hutang jangka pendek yang memiliki hubungan signifikan negatif dengan rasio likuiditas (LIQ). Merupakan hubungan yang menarik antara hutang jangka pendek PT XYZ dengan rasio likuditas PT XYZ atau kemampuan dari perusahaan dalam membayar hutang jangka pendeknya. Gill et al. (2011), menghitung rasio hutang jangka pendek dengan membaginya dengan aset perusahaan (aktiva lancar + aktiva tetap), rasio ini dimaksud menghitung seberapa besaran proporsi hutang jangka pendek perusahaan dibandingkan dengan total aset dari perusahaan tersebut. Rasio likuiditas (LIQ), Ross et al. (2010) menghitung dengan membagi aktiva lancar lancar perusahaan dengan hutang lancar perusahaan, hal ini dikarenakan Ross ingin mendapatkan rasio besaran proporsi aktiva lancar perusahaan dengan hutang lancar perusahaan. Rasio likuiditas sendiri dimaksud untuk mengetahui kemampuan perusahaan dalam membayar hutangnya dalam waktu jangka pendek, oleh karena itu rumus yang dipakai menggunakan aktiva lancar. Kedua akun tersebut, SDA dan rasio likuiditas akan selalu berbanding terbalik dan mempunyai hubungan signifikan negatif pada kinerja keuanganT XYZ.

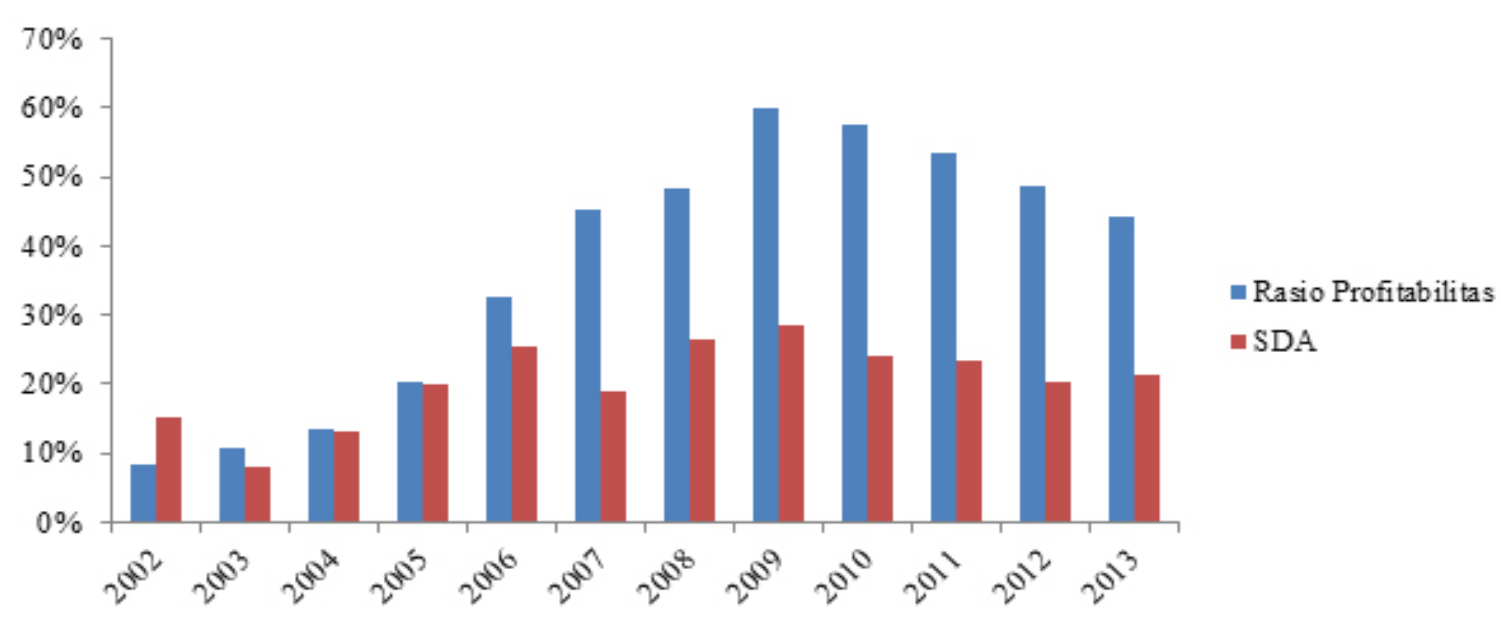

Gambar 8. Perbandingan rasio profitabilitas (ROE) dan rasio hutang jangka pendek SDA 


\section{Implikasi Manajerial}

Struktur modal perusahaan terlihat aset lancar lebih mendominasi ketimbang aset tetap selama kurun waktu pembukuan 2002-2013, inijuga merupakan bukti bahwa manajemen masih memerlukan pikir panjang dalam berinvestasi. Manajemen bisa mulai berinvestasi pada pembelian software atau mesin tandem terlebih dahulu, dikarenakan jasa pembayaran elektronis adalah bisnis yang mengandalkan kecanggihan teknologi dan sistem informasi, seharusnya hal tersebut menjadi kesempatan bagus untuk perkembangan. Pada analisis modal kerja Manajemen mulai harus memikirkan bagaimana cara memutar kas ditangan untuk menghasilkan revenue bagi perusahaan. Kas yang terlalu besar untuk deposito berjangka pada bank-bank memang baik untuk investasi jangka pendek, namun PT XYZ harus mulai melakukan investasi yang mendatangkan keuntungan bagi perusahaan secara real, investasi dengan membeli mesin software, hardware adalah satu hal yang dapat dilakukan namun akan membutuhkan waktu untuk mendatangkan keuntungan, investasi penanaman modal atau saham cukup berisiko. Namun, layak dicoba mengingat PT XYZ sudah merupakan perusahaan tergolong mature, manajemen harus bisa dan berani dalam mengelola kas ditangannya.

\section{KESIMPULAN DAN SARAN}

\section{Kesimpulan}

Pendekatan Modigliani and Miller (1958) dalam menghitung nilai perusahaan PT XYZ menjadi kurang sesuai, karena nilai perusahaan paling tinggi justru terjadi pada tahun 2013 dimana hutangnya pada saat itu hanya $26 \%$ dari total pasiva perusahaan. Menurut teori MM I dan MM II biaya modal perusahaan harusnya menjadi paling rendah pada tahun 2012, dan asumsi nilai perusahaan juga paling tinggi, mengingat rasio hutang paling tinggi ada pada tahun 2012. PT XYZ pada laporan neraca tahun 2002-2013 menambahkan seluruh keuntungan mereka untuk dimasukan kedalam modal perusahaan, akumulasi laba ditahan terbagi atas laba yang telah ditentukan penggunaanya pada pemegang saham, hal ini sesuai dengan teori pecking order yang dikemukan oleh Wet (2006), dimana urutan dalam menggunakan sumber pembiayaan perusahaan adalah i) dengan modal sendiri, ii) memanfaatkan pinjaman / hutang jangka panjang. Pada penelitian terlihat bahwa cara kedua adalah cara terakhir yang akan dilakukan perusahaan untuk mendapatkan dana.
Pendekatan konservatif perusahaan juga terlihat pada manajemen modal kerja, dimana PT XYZ memiliki modal kerja bersih dengan ciri low risk dan low return, dapat diartikan pula bahwa PT XYZ terlalu berhati-hati untuk mengambil risiko sehingga dana kas ditangan sebagian besar hanya di investasikan ke deposito berjangka bulanan pada bank. Ketika kebutuhan modal kerja kurang dikelola dengan kurang baik, akan menciptakan manajemen yang tidak efisien dan justru akan mengurangi manfaat dari investasi jangka pendeknya (Nazir dan Afza, 2009). Presentase aktiva lancar yang terlalu besar jika dibandingkan dengan total aktiva, kemungkinan memengaruhi profitabilitas secara negatif pada perusahaan (Belt, 1979), pada PT. XYZ proporsi jumlah aktiva lancar tahun buku 2002-2013 hampir selalu diatas 50\%, bahkan pada tahun 2011 aktiva lancar mencapai 60\% dari total aktiva, pada tahun 2013, proporsi menurun menjadi $38 \%$, dikarenakan pembelian server secara leasing, meskipun tidak memberikan dampak signifikan pada profitabilitas perusahaan, pada tahun 2011 terjadi penurunan laba perusahaan sekitar $4 \%$ dibandingkan dengan tahun sebelumnya.

Pada persamaan regresi didapat bahwa SDA berpengaruh signifikan terhadap semua rasio yang digunakan dalam mengukur company financial performance menurut Ross et al. (2010). Pada rasio profitabilitas perusahaan (ROE), hubungan signifikan SDA juga sesuai dengan penelitian dari Gill et al. (2011), dimana variabel struktur modal berpengaruh signifikan terhadap profitabilitas. Namun, pada WCR, dan NLB pada penelitian didapat tidak berpengaruh sama sekali terhadap profitabilitas, likuiditas dan solvabilitas, hal ini berbeda dengan Chiou et al. (2006) dimana working capital requirements menunjukan pengaruh signifikan negatif terhadap rasio solvabilitas. Pada persamaan LIQ didapat juga SDA yang berpengaruh signifikan negatif terhadap kemampuan perusahaan dalam membayar hutang jangka pendek/rasio likuiditas hal ini sesuai dengan penelitian yang dilakukan oleh Kajananthan dan Achchuthan (2013), pada persamaan LEV dapat terdapat dua variabel struktur modal yang berpengaruh signifikan, yaitu SDA dan LDA yang berpengaruh signifikan positif terhadap kemampuan perusahaan dalam membayar hutang jangka panjangnya, hal ini sesuai dengan penelitian Nurdin (2013), dimana level LEV berhubungan positif terhadap keinginan perusahan untuk menambah hutang atau menjual ekuitasnya (manajemen struktur modal) hal ini juga berarti hutang jangka pendek perusahaan jauh lebih memengaruhi 
performa keuangan perusahaan lebih besar dari yang diperkirakan.

\section{Saran}

Teori pecking order berarti PT XYZ lebih mementingkan mendapatkan return yang tetap, struktur modalnya lebih dipengaruhi oleh pertumbuhan perusahaan dan profitabilitas (Wet, 2006). Hal ini juga terlihat di laporan keuangan perusahaan dimana modal bertambah seiring dengan bertambahnya laba perusahaan. Hal ini dapat bisa menjadi nilai positif, pun negatif bagi manajemen. Positif dilihat dari laporan keuangan perusahaan tahun berjalan dimana nilai perusahaan sangat bagus. Namun, dari sisi struktur modal terlihat jelas perusahaan tidak ingin adanya investor lain mengambil alih saham perusahaan sehingga menambah modal perusahaan dengan cara menjual saham atau menjadi Tbk adalah hal terakhir yang akan dilakukan oleh PT XYZ.

Pada analisis modal kerja, kas ditangan masih merupakan sorotan bagi penelitian, pada pembahasan dapat dilihat bahwa setiap tahunnya modal kerja bersih perusahaan dalam melakukan kegiatan usahanya bernilai positif. Hampir sama dengan implikasi pada struktur modal, dalam manajemen modal kerja perusahaan masih melakukan pendekatan koservatif, pendekatan ini memiliki risiko likuiditas rendah dan hasil juga rendah. Manajemen mulai harus memikirkan bagaimana cara memutar kas ditangan untuk menghasilkan revenue bagi perusahaan.

Manajemen dalam mengolah modal kerja dan struktur modal perusahaan selama 12 tahun terakhir dapat disimpulkan bahwa hal yang mereka lakukan, dalam mengolah struktur modal berpengaruh signifikan terhadap kinerja perusahaan terutama kemampuan perusahaan dalam mengelola hutang jangka pendek dan aset perusahaan, untuk kedepannya, PT XYZ harus mampu mengurangi jumlah hutangnya, baik hutang jangka pendek ataupun hutang jangka panjang, menghitung lamanya pembayaran, risiko hutang terlalu lama tidak dibayar, karena hutang perusahaan ternyata berpengaruh signifikan terhadap kinerja perusahaan lebih besar daripada yang diperkirakan.

\section{DAFTAR PUSTAKA}

Abbadi MS, Abbadi TR. 2013. The determinant of working capital requirements in Palestinian industrial corporation. International Journal of Economic and Finance 5(1):65-75.

Azhar EN, Noriza, 2010. Working capital management: the effect of market valuation and profitability in Malaysia. International Journal of Business and Management 5(11):140-147.

Belt B. 1986. Working capital policy and liquidity in the small business. Journal of Small Business Mangement 17(3):43-51.

Bank Indonesia [BI]. 2012. Laporan Sistem Pembayaran dan Pengelolaan Uang 2012. Jakarta: Dept Akunting dan Sistem Pembayaran Dept Pengelolaan uang BI.

Chiou JR, Cheng L, Wu HW. 2006, The determinants of working capital management, Journal Of American of Business 10(1): 149-155.

Darminto, MAH. 2008. Pengujian teori trade off dan pecking order dengan satu model dinamis pada perusahaan publik di Indonesia. Jurnal Manajemen Bisnis 1(1): 35-51.

Wet D. 2006. Determining the optimal capital structure: a practical contemporary approach. Meditari Accountancy research 14(2) : 1-16.

Eldomiaty I T. 2007. Determinants of corporate capital structure: evidence from an emerging economy. International Journal of Commerce \& Management 17(2): 25-43.

Gill A, Biger N, Mand SH, Shah C. 2012. Corporate governance and capital structure of small business service firms in India. International Journal of Economics and Finance 4(8): 83-92.

Hair Jr, Black CW, Anderson ER, Tatham LR. 2006. Multivariate Data Analysis, Sixth Edition. UK: Pearson International Edition, Pearson Education.

Kajananthan R, Achchuthan S. 2013. Liquidity and capital strucure to Sri Lanka Telecom Plc. Advances in Mangement \& Applied Economics 3(5):89-99.

Myers SC, Majluf NS. 2001.Corporate financing and investment decisions when firm have information that investor do not have. Journal of Financial Economies 13: 187-221.

Mouamer, FMA. 2011. The determinants of capital structure of palestine listed companies. The Journal of Risk Finance 12(3): 226-241.

Modigliani F, Miller HM. 1958. The cost of capital, 
corporation finance and the theory of investment. The American Economic Review 48(3):261296.

Nurdin AK. 2013. Towards optimal capital structure: sharing risk of high leverage. International Journal of Innovation in Business 2(4): 373394.

Nazir MS, Afza T. 2009. Working capital requirements and the determining factors in pakistan. The IUP Journal of Applied Finance 15(4): 29-38.

Ranjith BA. 2008. The Impact of firms capital expenditure on working capital management: an empirical study across industries in Thailand. International Management Review 4(1): 8-21.

Ross AS, Westerfield WR, Jaffe J. 2010, Corporate Finance, Ninth Edition. UK: McGraw-Hill International Edition.

Shubita, MF, Alsawalhah JM. 2012. The relationship between capital structure and profitability, International Journal of Business and Social Science 3(16): 104-112.

Sutrisno. 2012. Manajemen Keuangan Teori Konsep dan Aplikasi. Yogyakarta: Ekonisia, Fakultas Ekonomi Universitas Islam Indonesia. 